\title{
RESEARCH PAPER \\ Quality, bioactive compounds, and antioxidant activity of serrano chili peppers cultivated in volcanic rock-vermicompost and nutrient solutions
}

\author{
Elia Cruz-Crespoํㅡㄹ María T. Sumaya-Martínez ${ }^{2}$, Álvaro Can-Chulim ${ }^{1}$, Joel \\ Pineda-Pineda ${ }^{3}$, Rubén Bugarín-Montoya ${ }^{1}$, and Gisela Aguilar-Benítez ${ }^{4}$ \\ ${ }^{1}$ Universidad Autónoma de Nayarit, Unidad Académica de Agricultura, Ctra. Tepic-Compostela km 9, CP \\ 63780, Xalisco, Nayarit, Mexico.
}

${ }^{2}$ Universidad Autónoma de Nayarit, Unidad de Tecnología de Alimentos, Cd. de la Cultura Amado Nervo S/N, CP 63190, Tepic, Nayarit, Mexico.

${ }^{3}$ Universidad Autónoma Chapingo, Departamento de Suelos, Carretera México-Texcoco km 38.5, CP 56230, Texcoco, estado de Mexico, Mexico.

${ }^{4}$ Universidad Autónoma de San Luis Potosí, Instituto de Investigación de Zonas Desérticas, Altair 200. Col. Del Llano, CP 78377, San Luis Potosí, Mexico.

\begin{abstract}
E. Cruz-Crespo, M.T. Sumaya-Martínez, Á. Can-Chulim, J. Pineda-Pineda, R. BugarínMontoya and G.Aguilar-Benítez. 2015. Quality, bioactive compounds, and antioxidant activity of serrano chili peppers cultivated in volcanic rock-vermicompost and nutrient solutions. Cien. Inv. Agr. 42(3): 375-384. The concentration of antioxidant compounds, the antioxidant activity, physical quality characteristics, and the yield of serrano chilies (Capsicum annuum L.) are affected by agricultural practices, such as the use of vermicompost in containers combined with chemical fertilizers, the investigations of which have focused on yield. A study was performed to determine whether vermicompost mixed with volcanic rock and the ionic composition of the nutrient solution affect the variables mentioned above. Serrano chilies were planted in volcanic rock:vermicompost in the following proportions 100:0, 80:20 and 60:40 and were watered with Steiner nutrient solution at 25,50 , and $75 \%$. Interaction of the factors was determined for the fresh weight of the fruits. Fruit length, diameter, number, weight, yield, firmness, hue, and chroma increased with the nutrient solutions at 50 and $75 \%$. Ascorbic acid levels fell with the solutions at 50 and $75 \%$, and total phenols and antioxidant activity increased with the solutions at 25 and $50 \%$. The 80:20 and 60:40 volcanic rock:vermicompost substrates similarly increased the length, diameter, number, weight, total phenols and antioxidant activity of the fruit. Yield increased with a greater proportion of the vermicompost. The solution at 50\% and the volcanic rock:vermicompost mixture 80:20 were the best conditions for the content of phenolic compounds, antioxidant activity, as well as diverse quality variables, although the 60:40 proportion was more favorable for yield.
\end{abstract}

Key words: Ascorbic acid, Capsicum annuum, phenols, yields

Received March 4, 2015. Accepted November 1, 2015.

Corresponding author: ccruzc2006@yahoo.com.mx 


\section{Introduction}

The Capsicum annuum L. fruits are the most consumed worldwide and are a source of bioactive compounds, such as polyphenols and ascorbic acid, which have antioxidant properties related to the prevention of degenerative diseases (Tundis et al., 2013). On the other hand, the commercial price of chili peppers is determined by quality attributes, such as the characteristics of color, firmness, and size (Abbot, 1999).

Currently, given the problems with production in the field, the production of vegetables in greenhouses through the use of organic or mineral media has increased. In this regard, the use of the compost and vermicompost in containers has increased over the past several years, slowly replacing the use of soil (Ali et al., 2007), which is attributed to the current tendency of using environmentally friendly materials. However, their use is reported in mixtures with other materials, with or without the use of nutrient solutions in different concentrations (De Grazia et al., 2007; Cruz-Crespo et al., 2014) to improve the physical properties of the growing medium and to reduce the use of chemical fertilizers, focusing on the study of the variables related to nutrition and yield. Therefore, information is scarce regarding the effects on the physical quality characteristics and the content of antioxidant compounds (ascorbic acid, phenolic compounds) and antioxidant activity. In this respect, Patthamakanokporn et al. (2008) and Erba et al. (2013) noted that these characteristics and the levels of antioxidant compounds are affected by several factors, such as pre- and post-harvest management, and the pattern of the effect can vary among species.

Regarding pre-harvest management, there are few reports on the use of organic manures on some vegetables in soil, where increases were found in the contents of ascorbic acid, phenolic compounds, and the antioxidant activity of tomatoes (Solanum lycopersicum L.) (Toor et al., 2006), cucumber (Cucumis sativus L.), and cab- bage (Brassica oleracea L.) (Pavla and Pokluda, 2008). In regard to the use of chemical fertilizers, there is only information on the effect of the form and dose of nitrogen on the compounds mentioned (Smolen and Sady, 2009). Therefore, the aim of this investigation was to contrast the proportions of vermicompost and volcanic rock in combination with different levels of Steiner nutrient solution on the physical characteristics of the serrano chili, its yield, ascorbic acid, total phenols, and antioxidant activity.

\section{Materials and methods}

\section{Experimental site}

The experiment was performed between July 15, 2012 and January 30, 2013 in a greenhouse located at $21^{\circ} 25^{\prime} 40^{\prime \prime} \mathrm{N}, 104^{\circ} 53^{\prime} 30^{\prime \prime} \mathrm{W}$ and 974 m.a.s.l. The high and low temperatures were 38 and 23 ${ }^{\circ} \mathrm{C}$, respectively, the average relative humidity was $83 \%$, and the light intensity was $463 \mu \mathrm{mol} \cdot \mathrm{m}^{-2} \cdot \mathrm{s}^{-1}$.

\section{Substrates and crop management}

The substrates were composed of mixtures of volcanic rock (VR) and vermicompost (VC) in different proportions (VR/VC, 100:0, 80:20 and $60: 40 \mathrm{v} / \mathrm{v})$ (Table 1). The sizes of the volcanic rock particles were 0.3 to $10 \mathrm{~mm}$, and the vermicompost particle size was 0.5 to $3.3 \mathrm{~mm}$. The latter was made using mango stone-sugar cane bagasse-bovine manure (1:1:1). 'Tampiqueño' serrano chili seeds were sown into 200-cell plug trays, using a mixture of perlite plus coconut fiber 50:50 (v/v). Then, seeds were irrigated with Steiner nutrient solution at 25\% (Steiner, 1984) until the time of the transplant.

Forty-five days after planting, one 'Tampiqueño' serrano chili seedling was placed in a pot made of black $35 \times 35 \mathrm{~cm}$ polyethylene. The pots were distributed randomly in rows with a separation of one meter and $45 \mathrm{~cm}$ between pots. 
Table 1. Chemical and nutritional properties of the substrates used (VC: vermicompost; VR: volcanic rock).

\begin{tabular}{lccccccccc}
\hline $\begin{array}{l}\text { Materials or } \\
\text { substrates }\end{array}$ & $\mathrm{pH} \mathrm{1:2}$ & $\mathrm{EC} 1: 2$ & $\mathrm{OM}$ & $\mathrm{CEC}$ & $\mathrm{N}$ & $\mathrm{P}$ & $\mathrm{K}$ & $\mathrm{Ca}$ & $\mathrm{Mg}$ \\
\hline & & $\mathrm{dSm}^{-1}$ & $\%$ & $\mathrm{Cmol}_{(+)} \mathrm{kg}^{-1}$ & & & $\%$ & & \\
VC & $8.1^{1}$ & 4.72 & 30 & 44.3 & 1.24 & 1.84 & 2.02 & 2.56 & 0.63 \\
VR/VC, 80:20 & 6.0 & 0.33 & 3.8 & 6.88 & 0.20 & 0.30 & 0.38 & 0.54 & 0.11 \\
VR/VC, 60:40 & 6.2 & 0.72 & 10.5 & 15.3 & 0.38 & 0.62 & 0.83 & 1.31 & 0.22 \\
\hline
\end{tabular}

${ }^{1}$ Average of three determinations; $\mathrm{pH}=$ potential of hydrogen; $\mathrm{EC}=$ electrical conductivity; $\mathrm{OM}=$ organic matter; $\mathrm{CEC}=$ cation exchange capacity.

Drip irrigation was initiated using the Steiner nutrient solution at concentrations of 25,50 , or $75 \%$, which was prepared using the fertilizers $\mathrm{Ca}\left(\mathrm{NO}_{3}\right)_{2} \cdot 4 \mathrm{H}_{2} \mathrm{O}, \mathrm{KNO}_{3}, \mathrm{MgSO}_{4} \cdot 7 \mathrm{H}_{2} \mathrm{O}, \mathrm{KH}_{2} \mathrm{PO}_{4}$, $\mathrm{K}_{2} \mathrm{SO}_{4}$, and $\mathrm{HNO}_{3}$. For micronutrients, a stock solution was prepared with $2.8 \mathrm{~g} \cdot \mathrm{L}^{-1}$ of $\mathrm{H}_{3} \mathrm{BO}_{3}$, $2.2 \mathrm{~g} \cdot \mathrm{L}^{-1}$ of $\mathrm{MnSO}_{4} \cdot \mathrm{H}_{2} \mathrm{O}, 0.4 \mathrm{~g} \cdot \mathrm{L}^{-1}$ of $\mathrm{ZnSO}_{4}, 0.08$ $\mathrm{g} \cdot \mathrm{L}^{-1}$ of $\mathrm{CuSO}_{4}, 0.1 \mathrm{~g} \cdot \mathrm{L}^{-1}$ of $\mathrm{Na}_{2} \mathrm{MoO}_{4}$, and $3 \mathrm{mg} \cdot \mathrm{L}^{-1}$ of Fe-EDTA. Of this solution, $1 \mathrm{~mL}$ was used for every liter of Steiner nutrient solution. The $\mathrm{pH}$ of the solutions was adjusted to 6.0. Water use was $200 \mathrm{~mL}$ for each irrigation trial, which took place $2-6$ times a day, depending on the water requirements (leaching fraction was $25 \%$ ).

\section{Experimental design and treatments}

Treatments formed a factorial arrangement $3 \times 3$ corresponding to three nutrient solution concentrations (Steiner nutrient solution at 25, 50, and 75\%) and three substrates (VR/VC, 100:0; 80:20 and 60:40 $\mathrm{v} / \mathrm{v}$ ), in a randomized experimental design with eight replications. For fruit yield, the experimental unit was a plant in a pot. For the fruit quality variables, the experimental unit consisted of 20 fruits per plant. For bioactive compounds and antioxidant activity, the experimental unit was one fruit per plant.

\section{Fruit quality and yield variables}

Fruits that did not present corkiness or curvature were evaluated, as well as those that reached a length of $\geq 5 \mathrm{~cm}$. Fruit length and fruit equatorial diameter $(\mathrm{cm})$ were measured with a Truper ${ }^{\mathbb{B}}$ digital vernier caliper. The number of fruits per harvest was counted. The weight of each fruit and fruit yield per plant (g) were obtained using an OHAUS Explorer ${ }^{\circledR}$ electronic balance. Fruit size was classified according to the specifications of the Official Mexican Standard NMX-FF-025-SCFI-2013 (SE, 2014). Evaluations were conducted on October 24, 2012 (first harvest), November 15, 2012 (second harvest), December 13, 2012 (third harvest), and January 19, 2013 (fourth harvest).

Additionally, during the third harvest, the firmness $\left(\mathrm{N} \cdot \mathrm{cm}^{-2}\right)$ was determined using the Force Gauge model Gy-4 texturometer with a $0.5 \mathrm{~cm}$ diameter concave tip. Readings were taken on opposite sides of the fruit, and the average was calculated. For hue and chroma, a Konica Minolta Optics, Inc. 1865945 colorimeter was used to obtain the readings of parameters $a$ and $b$ of the opposite sides of the fruit. Then, the hue angle $=\tan ^{-1} \mathrm{~b} / \mathrm{a}$ and chroma $=\left(a^{2}+b^{2}\right)^{1 / 2}$ were calculated.

\section{Bioactive compounds and antioxidant activity}

To prepare the sample, $6 \mathrm{~g}$ of the pericarp of the chili was weighed and blended with $30 \mathrm{~mL}$ of oxalic acid at 3\%. Later, the sample was filtered using Whatman filter paper and was stored at $-20^{\circ} \mathrm{C}$. The sample was extracted from $5 \mathrm{~g}$ of the pericarp of the chili and was blended with $25 \mathrm{~mL}$ of oxalic acid at 3\%, centrifuged at 5,000 rpm for $10 \mathrm{~min}$, filtered through a $0.45 \mu \mathrm{m}$ Millipore hydrophilic PVDF syringe filter and frozen at $-20^{\circ} \mathrm{C}$.

Acid ascorbic content was determined according to Dürüst et al. (1997). Briefly, $100 \mu \mathrm{L}$ of the sample (a different dilution factor in oxalic acid 
at $0.4 \%$ was used for each sample) was added to $100 \mu \mathrm{L}$ of acetate buffer, and then $800 \mu \mathrm{L}$ of DCPI (2,6-dichloroindophenol sodium) was added. The absorbance of the mixture was measured immediately at $520 \mathrm{~nm}$ in a microplate reader (PowerWave XS, Biotek instruments, USA). Ascorbic acid (ASC A) was used as a reference standard, and the results were expressed as $\mathrm{mg}$ ascorbic acid $100 \mathrm{~g}^{-1}$ of fruit.

Total phenol content (TPC) was determined according to Georgé et al. (2005). Briefly, $100 \mu \mathrm{L}$ of the methanolic extract was added to $500 \mu \mathrm{L}$ of 1:10 diluted Folin-Ciocalteu reagent, and $400 \mu \mathrm{L}$ of sodium carbonate solution (at 7.5\%) was added. After incubation at room temperature for $30 \mathrm{~min}$, the absorbance of the mixture was measured at $765 \mathrm{~nm}$ in a microplate reader (PowerWave XS. Biotek Instruments). Gallic acid was used as a reference standard, and the results were expressed as the equivalent of milligrams of gallic acid (mg $\mathrm{GAE} \cdot 100 \mathrm{~g}^{-1}$ of fruit).

Antioxidant activity was measured using DPPH (1,1-Diphenyl-2-picrylhydrazyl radical), as described by Morales and Jimenez-Pérez (2001). A $7.4 \mathrm{mg} \cdot 100 \mathrm{~mL}^{-1}$ ethanolic solution of the stable DPPH radical was prepared. Next $100 \mu \mathrm{L}$ of the samples were taken into vials, and $500 \mu \mathrm{L}$ of DPPH solution was added. The solution was stirred in a vortex and centrifuged at 10,000 rpm for $5 \mathrm{~min}$ after standing for one hour at room temperature. Finally, absorbance was measured at $520 \mathrm{~nm}$ in a microplate reader, and $\mu \mathrm{mol}$ equivalents of Trolox $\cdot \mathrm{g}^{-1}$ of fruit was obtained.

\section{Statistical analyses}

Data were analyzed by analysis of variance and the Tukey comparison of means at $5 \%$ probability. Correlations were determined between variables. Polynomial regression models were also obtained. SAS version 8 software was used for the statistical analysis (SAS Institute, Cary, North Carolina, USA).

\section{Results and discussion}

\section{Fruit quality and yield}

Substrate-nutrient solution interaction. The interaction of the factors displayed a significant increase in fruit weight $(\mathrm{P} \leq 0.0095)$ on the four harvest dates (Table 2). The interaction effect of nutrient solution and substrate contributed to the sum of squares of treatments from 10.7 to $14 \%$, considering the four harvest dates. Meanwhile, the solution factor contributed 31.4 to $46.9 \%$, and the substrate contributed 39 to $57.9 \%$. For fruit diameter, the interaction was significant $(\mathrm{P} \leq 0.0424)$, although the tendency was not clear (Table 2).

Nutrient solution factor. On the four harvest dates, comparison of means expressed differences due to the effects of the nutrient solution, in which the S50 and S75 treatments contrasted with that of S25 by approximately $10 \%$ for fruit length and fruit diameter and between 15 and 19\% for fruit weight, without differences between S50 and S75 (Table 3).

Fruit numbers increased significantly in response to the proportional increase of the ionic concentration in the nutrient solution. On the other hand, the fruits of the first and second harvests were classified as small, whereas for the third and fourth harvests, fruits with S25 were classified as small, and those obtained with S50 and S75 were classified as medium.

The yield behavior over time in the different nutrient solutions is shown in Figure 1, which indicates a significant difference of 124 to $203 \mathrm{~g}$ between S50 and S25 and of 174 to $252 \mathrm{~g}$ between S75 and S25, with no differences between S50 and S75. A positive relation was also obtained for fruit yield with the variables related to fruit size and number fruits $(\mathrm{R}=0.46$ to $0.01 \%$ between the variables fruit yield and diameter, $R=0.5$ to $0.01 \%$ between yield and fruit length, $\mathrm{R}=0.84$ to $0.01 \%$ between variables fruit yield and number). 
Table 2. Fruit weight and diameter for 'Tampiqueño' serrano chili by substrate-nutrient solution interaction of three harvests from 2012-2013.

\begin{tabular}{|c|c|c|c|c|c|c|c|c|c|}
\hline \multirow[b]{2}{*}{ Substrate } & \multicolumn{3}{|c|}{ Second harvest } & \multicolumn{3}{|c|}{ Third harvest } & \multicolumn{3}{|c|}{ Fourth harvest } \\
\hline & $\mathrm{S} 25$ & S50 & S75 & $\mathrm{S} 25$ & S50 & S75 & $\mathrm{S} 25$ & S50 & S75 \\
\hline \multicolumn{10}{|l|}{ Fruit weight (g) } \\
\hline $\mathrm{VR} / \mathrm{VC}, 100: 0$ & $5.34 \mathrm{~b}^{1}$ & $5.50 \mathrm{~b}$ & $6.00 \mathrm{~b}$ & $5.20 \mathrm{c}$ & $5.33 \mathrm{~b}$ & $6.00 \mathrm{~b}$ & $5.20 \mathrm{c}$ & $5.37 \mathrm{~b}$ & $6.00 \mathrm{~b}$ \\
\hline $\mathrm{VR} / \mathrm{VC}, 80: 20$ & $5.54 \mathrm{a}$ & $6.83 \mathrm{a}$ & $6.86 \mathrm{a}$ & $5.73 \mathrm{a}$ & $7.51 \mathrm{a}$ & $7.36 \mathrm{a}$ & $5.89 \mathrm{a}$ & $7.36 \mathrm{a}$ & $7.38 \mathrm{a}$ \\
\hline $\mathrm{VR} / \mathrm{VC}, 60: 40$ & $5.43 \mathrm{~b}$ & $6.83 \mathrm{a}$ & $6.84 \mathrm{a}$ & $5.52 \mathrm{~b}$ & $7.61 \mathrm{a}$ & $7.38 \mathrm{a}$ & $5.70 \mathrm{~b}$ & $7.47 \mathrm{a}$ & $7.41 \mathrm{a}$ \\
\hline \multicolumn{10}{|c|}{ Fruit diameter $(\mathrm{cm})$} \\
\hline $\mathrm{VR} / \mathrm{VC}, 100: 0$ & $1.13 \mathrm{c}$ & $1.41 \mathrm{~b}$ & $1.43 \mathrm{~b}$ & $1.29 \mathrm{~b}$ & $1.41 \mathrm{~b}$ & $1.47 \mathrm{a}$ & $1.41 \mathrm{a}$ & $1.44 \mathrm{~b}$ & $1.54 \mathrm{~b}$ \\
\hline $\mathrm{VR} / \mathrm{VC}, 80: 20$ & $1.44 \mathrm{~b}$ & $1.50 \mathrm{a}$ & $1.51 \mathrm{a}$ & $1.51 \mathrm{a}$ & $1.54 \mathrm{a}$ & $1.55 \mathrm{a}$ & $1.46 \mathrm{a}$ & $1.64 \mathrm{a}$ & $1.64 \mathrm{a}$ \\
\hline $\mathrm{VR} / \mathrm{VC}, 60: 40$ & $1.50 \mathrm{a}$ & $1.59 \mathrm{a}$ & $1.44 \mathrm{~b}$ & $1.51 \mathrm{a}$ & $1.54 \mathrm{a}$ & $1.49 \mathrm{a}$ & $1.46 \mathrm{a}$ & $1.61 \mathrm{a}$ & $1.59 \mathrm{ab}$ \\
\hline
\end{tabular}

${ }^{1}$ Values followed by the same letter in the same column do not differ significantly (Tukey, $\mathrm{P} \leq 0.05$ ). S25 = nutrient solution at $25 \%$; S50 = nutrient solution at 50\%; S75 = nutrient solution at $75 \%$. VC $=$ vermicompost; $\mathrm{VR}=$ volcanic rock.

Table 3. Fruit length (FL), fruit diameter (FD), fruit number (FN), and fruit weight (FW) of 'Tampiqueño' serrano chili in four harvests during 2012-2013.

\begin{tabular}{|c|c|c|c|c|c|c|c|c|}
\hline \multirow[b]{2}{*}{ Solution } & $\begin{array}{c}\mathrm{FL} \\
(\mathrm{cm})\end{array}$ & $\begin{array}{l}\text { FD } \\
(\mathrm{cm})\end{array}$ & $\mathrm{FN}$ & $\mathrm{FW}(\mathrm{g})$ & $\mathrm{FL}(\mathrm{cm})$ & $\begin{array}{l}\text { FD } \\
(\mathrm{cm})\end{array}$ & $\mathrm{FN}$ & $\begin{array}{r}\text { FW } \\
(\mathrm{g})\end{array}$ \\
\hline & \multicolumn{4}{|c|}{ First harvest } & \multicolumn{4}{|c|}{ Second harvest } \\
\hline S25 & $6.45 \mathrm{a}^{1}$ & $1.27 \mathrm{~b}$ & $45.00 \mathrm{c}$ & $5.27 \mathrm{c}$ & $6.45 \mathrm{~b}$ & $1.36 \mathrm{~b}$ & $32.44 \mathrm{c}$ & $5.43 \mathrm{~b}$ \\
\hline S50 & $6.42 \mathrm{a}$ & $1.45 \mathrm{a}$ & $52.16 \mathrm{~b}$ & $5.37 \mathrm{~b}$ & $7.12 \mathrm{a}$ & $1.47 \mathrm{a}$ & $46.39 \mathrm{~b}$ & $6.39 \mathrm{a}$ \\
\hline S75 & $6.68 \mathrm{a}$ & $1.45 \mathrm{a}$ & $62.05 \mathrm{a}$ & $5.44 \mathrm{a}$ & $7.17 \mathrm{a}$ & $1.46 \mathrm{a}$ & $55.05 \mathrm{a}$ & $6.44 \mathrm{a}$ \\
\hline \multicolumn{9}{|l|}{ Substrate } \\
\hline $\mathrm{VR} / \mathrm{VC}, 100: 0$ & $6.28 \mathrm{~b}$ & $1.25 \mathrm{~b}$ & $52.44 \mathrm{a}$ & $5.22 \mathrm{~b}$ & $6.67 \mathrm{~b}$ & $1.32 \mathrm{~b}$ & $38.44 \mathrm{~b}$ & $5.49 \mathrm{~b}$ \\
\hline $\mathrm{VR} / \mathrm{VC}, 80: 20$ & $6.47 \mathrm{ab}$ & $1.45 \mathrm{a}$ & $55.05 \mathrm{a}$ & $5.42 \mathrm{a}$ & $7.00 \mathrm{ab}$ & $1.48 \mathrm{a}$ & $42.44 \mathrm{~b}$ & $6.41 \mathrm{a}$ \\
\hline VR/VC, $60: 40$ & $6.91 \mathrm{a}$ & $1.47 \mathrm{a}$ & $51.72 \mathrm{a}$ & $5.44 \mathrm{a}$ & $7.09 \mathrm{a}$ & $1.48 \mathrm{a}$ & $53.00 \mathrm{a}$ & $6.36 \mathrm{a}$ \\
\hline CV (\%) & 8.76 & 5.85 & 7.98 & 1.4 & 6.54 & 3.18 & 22.38 & 2.5 \\
\hline Solution & \multicolumn{4}{|c|}{ Third harvest } & \multicolumn{4}{|c|}{ Fourth harvest } \\
\hline S25 & $6.65 \mathrm{~b}$ & $1.43 \mathrm{~b}$ & $49.77 \mathrm{~b}$ & $5.48 \mathrm{~b}$ & $6.64 \mathrm{~b}$ & $1.44 \mathrm{~b}$ & $30.66 \mathrm{c}$ & $5.60 \mathrm{~b}$ \\
\hline $\mathrm{S} 50$ & $7.53 \mathrm{a}$ & $1.49 \mathrm{ab}$ & $66.44 \mathrm{a}$ & $6.81 \mathrm{a}$ & $7.40 \mathrm{a}$ & $1.56 \mathrm{a}$ & $50.77 \mathrm{~b}$ & $6.73 \mathrm{a}$ \\
\hline S75 & $7.46 \mathrm{a}$ & $1.50 \mathrm{a}$ & $70.77 \mathrm{a}$ & $6.75 \mathrm{a}$ & $7.46 \mathrm{a}$ & $1.58 \mathrm{a}$ & $63.55 \mathrm{a}$ & $6.78 \mathrm{a}$ \\
\hline \multicolumn{9}{|l|}{ Substrate } \\
\hline $\mathrm{VR} / \mathrm{VC}, 100: 0$ & $6.54 \mathrm{~b}$ & $1.39 \mathrm{~b}$ & $52.94 \mathrm{~b}$ & $5.34 \mathrm{~b}$ & $6.40 \mathrm{~b}$ & $1.46 \mathrm{~b}$ & $32.11 \mathrm{~b}$ & $5.37 \mathrm{~b}$ \\
\hline $\mathrm{VR} / \mathrm{VC}, 80: 20$ & $7.65 \mathrm{a}$ & $1.53 \mathrm{a}$ & $63.28 \mathrm{ab}$ & $6.86 \mathrm{a}$ & $7.56 \mathrm{a}$ & $1.57 \mathrm{a}$ & $53.33 \mathrm{a}$ & $6.87 \mathrm{a}$ \\
\hline $\mathrm{VR} / \mathrm{VC}, 60: 40$ & $7.45 \mathrm{a}$ & $1.51 \mathrm{a}$ & $70.78 \mathrm{a}$ & $6.84 \mathrm{a}$ & $7.54 \mathrm{a}$ & $1.55 \mathrm{a}$ & $59.55 \mathrm{a}$ & $6.86 \mathrm{a}$ \\
\hline CV (\%) & 12.62 & 5.25 & 22.96 & 3.05 & 8.96 & 3.56 & 19.17 & 3.67 \\
\hline
\end{tabular}

${ }^{1}$ Values followed by the same letter in the same column do not differ significantly (Tukey, $\mathrm{P} \leq 0.05$ ). $\mathrm{S} 25=$ nutrient solution at $25 \%$; S50 = nutrient solution at 50\%; S75 = nutrient solution at $75 \%$. VC $=$ vermicompost; VR $=$ volcanic rock.

Information is scarce in relation to the variables fruit length, diameter and weight due to the use of nutritive solutions. There are some reports regarding fruit yield. Godoy-Hernández et al. (2009) noted that using a nutritive solution in concentrations of 50 and $75 \%$ caused no differ- ences in the yield of tomato fruits. Therefore, the results depend on the species.

According to results obtained by the effect of the nutrient solution in this investigation, a study is recommended on serrano chilies in substrates 
and in the greenhouse with solutions at a concentration of $>75 \%$. With solutions S50 and S75, the fruits became approximately $6 \mathrm{~N} \cdot \mathrm{cm}^{-2}$ firmer compared to S25 (Table 4). Additionally, hue and chroma had higher values with the S50 and S75 solutions, in which the chroma coincided with reports by Vázquez-García et al. (2010), whereas hue remained near the reported value.

These fruits acquired a more intense color (emerald green, characteristic of the 'Tampiqueño' variety) in comparison with the solution at $25 \%$, in which the color was much less intense (light green). CruzCrespo and Sandoval-Villa (2012) indicated that tomato fruits became firmer and had a higher hue value with the solution at $50 \%$ compared with nonapplication or greater ionic concentration in solution.

Substrate factor. InTable 3, the contrast of means shows substrates VR/VC,80:20 and VR/VC,60:40 as displaying the greatest length, diameter, weight and number of fruits in comparison to VR/VC,100:0, although for the first and second harvests in all substrates, all fruits reached a small size. In the third and fourth harvest, only substrates VR/ VC, 80:20 and VR/VC, 60:40 reached a medium size. This shows that vermicompost in the growth medium increase the fruit size.

Figure 1 shows the fruit yield over time. During the first and second harvests, a significant dif-

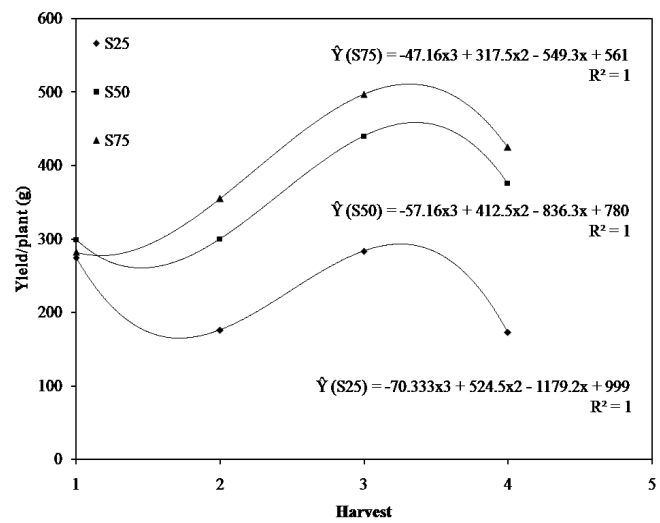

ference of 46 to $63 \mathrm{~g}$ was obtained between VR/ VC, 100:0 and VR/VC, 80:20 and 104 to $132 \mathrm{~g}$ between VR/VC, 100:0 and VR/VC, 60:40. The difference between the third and fourth harvests was $188 \mathrm{~g}$ between VR/VC, 100:0 and VR/VC, 80:20 and 213 to $271 \mathrm{~g}$ between VR/VC, 100:0 and VR/VC, 60:40. Vermicomposted materials are rich in nutrients, retain water and contain growth-regulating substances (Hernández et $a l, 2010)$, all of which contribute to greater fruit size and higher yields. There is scarce literature illustrating the effect of composts and vermicomposts on the variables studied here. In this respect, Silva et al. (2010) indicated that the combination of compost with soil in proportions of 25 to $75 \%$ increased the number of fruits in relation to the treatment without vermicompost. López-Espinosa et al. (2013) applied compost mixed with sand (1:1) plus a vermicompost tea for jalapeño chili (C. annuum) and obtained the same yield, length, diameter and number of fruits as with chemical fertilization. Therefore, a prior definition is recommended of the most adequate proportions when mixing materials.

Table 4 shows greater fruit firmness at 3.6 $\mathrm{N} \cdot \mathrm{m}^{-2}$ for the substrate VR/VC, 80:20 compared to $\mathrm{VR} / \mathrm{VC}, 60: 40$ and $6.68 \mathrm{~N} \cdot \mathrm{m}^{-2}$ compared to $\mathrm{VR} / \mathrm{VC}, 100: 0$. For hue and chroma, the values are approximately $118^{\circ}$ and 22 , respectively, without differences among substrates, which

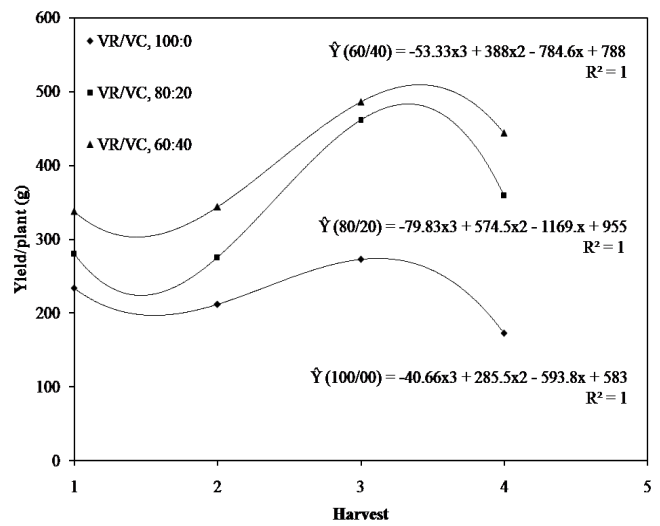

Figure 1. Fruit yield of 'Tampiqueño' serrano chili planted with different nutrient solutions (left) and different substrates (right) from 2012-2013. S25 = nutrient solution at 25\%; S50 = nutrient solution at 50\%; S75 = nutrient solution at 75\%. VC = vermicompost; $\mathrm{VR}=$ volcanic rock. 
Table 4. Firmness (FIR), hue (HUE), chroma (CHR), bioactive compounds (ASC A= ascorbic acid; $\mathrm{TPC}=$ total phenolic content) and antioxidant activity (AA) of third-harvest fruits of 'Tampiqueño' serrano chili.

\begin{tabular}{|c|c|c|c|c|c|c|}
\hline & $\begin{array}{c}\text { FIR } \\
\left(\mathrm{N} \mathrm{cm}^{2}\right)\end{array}$ & $\operatorname{HUE}\left(^{\circ}\right)$ & CHR & $\begin{array}{l}\text { ASC A } \\
\text { mg } 100 \mathrm{~g}^{-1} \\
\text { of fruit }\end{array}$ & $\begin{array}{c}\text { TPC } \\
\text { GAE mg } 100 \\
\mathrm{~g}^{-1} \text { of fruit }\end{array}$ & $\begin{array}{c}\text { AA } \\
\mu \text { moltrolox } g^{-1} \\
\text { of fruit }\end{array}$ \\
\hline \multicolumn{7}{|l|}{ Solution } \\
\hline S25 & $123.42 \mathrm{~b}^{1}$ & $108.34 \mathrm{~b}$ & $19.31 \mathrm{~b}$ & $41.19 \mathrm{a}$ & $64.73 \mathrm{a}$ & $2.49 \mathrm{a}$ \\
\hline S50 & $128.77 \mathrm{a}$ & $124.21 \mathrm{a}$ & $23.51 \mathrm{a}$ & $32.69 \mathrm{~b}$ & $62.95 \mathrm{a}$ & $2.23 \mathrm{a}$ \\
\hline S75 & $129.35 \mathrm{a}$ & $122.34 \mathrm{a}$ & $23.59 \mathrm{a}$ & $31.00 \mathrm{~b}$ & $55.07 \mathrm{~b}$ & $1.62 \mathrm{~b}$ \\
\hline \multicolumn{7}{|l|}{ Substrate } \\
\hline $\mathrm{VR} / \mathrm{VC}, 100: 0$ & $123.93 \mathrm{~b}$ & $117.79 \mathrm{a}$ & $21.75 \mathrm{a}$ & $30.71 \mathrm{a}$ & $57.68 \mathrm{~b}$ & $1.83 \mathrm{~b}$ \\
\hline $\mathrm{VR} / \mathrm{VC}, 80: 20$ & $130.61 \mathrm{a}$ & $119.08 \mathrm{a}$ & $22.71 \mathrm{a}$ & $36.57 \mathrm{a}$ & $65.48 \mathrm{a}$ & $2.25 \mathrm{ab}$ \\
\hline $\mathrm{VR} / \mathrm{VC}, 60: 40$ & $127.01 \mathrm{ab}$ & $118.50 \mathrm{a}$ & $21.95 \mathrm{a}$ & $37.63 \mathrm{a}$ & $59.58 \mathrm{ab}$ & $2.26 \mathrm{a}$ \\
\hline CV $(\%)$ & 4.09 & 8.0 & 9.62 & 15.81 & 9.56 & 14.97 \\
\hline
\end{tabular}

${ }^{1}$ Values followed by the same letter in the same column do not differ significantly (Tukey, $\mathrm{P} \leq 0.05$ ). GAE $=$ Gallic acid equivalents. S25 = nutrient solution at $25 \%$; S50 = nutrient solution at $50 \%$; S75 = nutrient solution at $75 \%$. VC $=$ vermicompost; $\mathrm{VR}=$ volcanic rock.

indicates that fruits were light green. The positive effect of vermicompost on firmness was also observed by Zaller (2007) on tomato fruits, although the results varied between the genotypes evaluated.

\section{Bioactive compounds and antioxidant activity}

Nutrient solution factor. The amount of ascorbic acid was $23 \%$ higher with the solution at $25 \%$ than in concentrations of 50 and $75 \%$, with no significant difference. For total content of phenols (Table 4), a $14 \%$ higher concentration was found with the solution S25 and S50 than with S100. Antioxidant activity maintained a similar tendency to that of the total phenolic content, in which S25 and S50 were greater by approximately $31 \%$. Additionally, a positive correlation was found between antioxidant activity and total phenolic content $(\mathrm{R}=0.61$, $\mathrm{P} \leq 0.01)$ and between antioxidant activity and ascorbic acid $(\mathrm{R}=0.55, \mathrm{P} \leq 0.01)$. This result was congruent with the results found in basil (Ocimum basilicum L.) plantations (Nguyen et al., 2010) and in the medicinal plant known as "King of bitters" (Andrographis paniculata B.) (Upadhyaya et al., 2011). There are few investigations on nutrient solutions or on the application of chemical fertilizers on the content of ascorbic acid, phenols, and antioxidant activity, and these investigations mainly report the effect of $\mathrm{N}$ or $\mathrm{K}$ levels, with conflicting reports. Hernández-Fuentes et al. (2010) evaluated two levels of fertilization with N-P-K on chili peppers (C. annum) and found no difference in the amounts of ascorbic acid. Likewise, Chiesa et al. (2009) showed that low $\mathrm{N}$ levels increased the levels of ascorbic acid in lettuce (Latuca sativa $\mathrm{L}$.). Zhu et al. (2009) found a higher amount of total phenols in cabbage plants with low doses of nitrogen. Nguyen et al. (2010) reported an increase in the amount of total phenols and antioxidant activity in basil leaves when increasing the concentration of $\mathrm{K}$ in the nutrient solution.

Substrate factor. No differences were found for the amount of ascorbic acid, due to the effect of the substrate (Table 4). In contrast, the total amount of phenols and antioxidant activity increased with substrates VR/VC, 80:20 and VR/ $\mathrm{VC}, 60: 40$, although the values were lower than those reported by Medina-Juárez et al. (2012). References are minimal in relation to the results of organic and inorganic growth media, or those amended with vermicompost in secondary metabolites. Picchi et al. (2012) showed that the total contents of phenols and ascorbic acids increase in the cauliflower (B. oleracea) Magnifico hybrid with the use of organic fertilizers in 
comparison with inorganic fertilizer, but this was contrary to the findings in the Emeraude hybrid. Faezah-Omar et al. (2012) reported, for cassava (Manihot esculenta C.) tubers, a higher amount of total phenols and antioxidant activity when treated with vermicompost than when chemical fertilizer was applied to the soil.

This study yielded several conclusions. The interaction of the nutrient solution and substrate exerted a positive effect on the fruit's fresh weight. Nutrient solutions at 50 and $75 \%$ increased, on the same scale, fruit length, diameter, weight, number, and yield, as well as firmness, hue, and chroma on the different harvest dates. However, the ascorbic acid content, total phenol content, and antioxidant activity decreased with the $75 \%$ solution; thus, the $50 \%$ solution was considered the most suitable. The volcanic rock substrate in combination with vermicompost in proportions of 80:20 and 60:40 similarly increased the fruit's length and firmness, phenolic content, and antioxidant activity, and fruit yield increased with the 60:40 proportion of volcanic rock:vermicompost.

\section{Resumen}

E. Cruz-Crespo, M.T. Sumaya-Martínez, Á. Can-Chulim, J. Pineda-Pineda, R. BugarínMontoya y G. Aguilar-Benítez. 2015. Calidad, compuestos bioactivos, y actividad antioxidante de chile serrano, cultivado en tezontle-lombricomposta y soluciones nutritivas. Cien. Inv. Agr. 42(3): 375-384. La concentración de los compuestos antioxidantes, la actividad antioxidante, las características físicas de calidad y rendimiento del chile serrano Capsicum annuum L. pueden ser afectados por las prácticas agrícolas tal como el uso de la lombricomposta en contenedor en combinación con fertilizantes químicos, cuyas investigaciones se han enfocado al rendimiento. Se llevó a cabo el estudio para conocer si la lombricomposta en mezcla con tezontle y la concentración iónica de la solución nutritiva afectan las variables arriba mencionadas. Se cultivó chile serrano en tezontle:lombricomposta en las proporciones 100:0, 80:20 60:40, y regado con las soluciones nutritivas a 25,50 y $75 \%$. Se encontró interacción de los factores para peso freso. La longitud, diámetro, número, peso y rendimiento de frutos así como firmeza, hue y croma incrementaron con las soluciones nutritivas a 50 y 75\%. El ácido ascórbico disminuyó con la solución a 50 y 75\%, y los fenoles totales y actividad antioxidante incrementaron con la solución a 25 y 50\%. El sustrato tezontle:lombricomposta 80:20 y 60:40 incrementaron de manera similar la longitud, diámetro, número, peso, fenoles totales y actividad antioxidante del fruto. El rendimiento incrementó a mayor proporción de lombricomposta. Se concluyó que la solución a $50 \%$ y la mezcla tezontle-lombricomposta en la proporción 80:20 fueron las más convenientes por favorecer el contenido de compuestos fenólicos, actividad antioxidante y diversas variables de calidad, aunque para mayor rendimiento fue más favorable la proporción 60:40.

Palabras clave: Ácido ascorbico, Capsicum annuum, fenoles, rendimiento.

\section{References}

Abbott, J.A. 1999. Quality measurement of fruit and vegetables. Postharvest, Biology and Technology 15: 207-225.

Ali, M., J. Griffiths, K.P. Williams, and D.L. Jones. 2007. Evaluating the growth characteristics of lettuce in vermicompost and green waste compost. European Journal of Soil Biology 43: 316-319.
Chiesa, A., I. Mayorga, and A. Leon. 2009. Quality of fresh cut lettuce (Lactuca sativa L.) as affected by lettuce genotype, nitrogen fertilization and crop season. Advances in Horticultural Science 23: 143-149.

Cruz-Crespo, E. and M. Sandoval-Villa. 2012. Effect of the nutrient solution concentration and substrates mixture con the quality of tomato. Acta Horticulturae 947: 197-202. 
Cruz-Crespo, E., A. Can-Chulim, R. Bugarín-Montoya, J. Pineda-Pineda, R. Flores-Canales, P. Juárez-López, and G. Alejo-Santiago. 2014. Leaf nutrient concentration and plant growth of chili serrano in relation to nutrient solution and substrate. Revista Fitotecnia Mexicana 37: 289-295.

De Grazia, J., P.A. Tittonell, and A. Chiesa. 2007. Efecto de sustratos con compost y fertilización nitrogenada sobre la fotosíntesis, precocidad y rendimiento de pimiento (Capsicum annuиm). Ciencia e Investigación Agraria 34: 195-204.

Dürüst, N., S. Dogan, and Y. Dürüst. 1997. Ascorbic acid and element contents of foods of trabzon (Turkey). Journal Agricultural Food Chemistry 45: 2085-2087.

Erba, D., M.C. Casiraghi, A. Ribas-Agustí, R. Cáceres, O. Marfa, and M. Castellari. 2013. Nutritional value of tomatoes (Solanum lycopersicum L.) grown in greenhouse by different agronomic techniques. Journal of Food Composition and Analysis 31: 245-251.

Faezah-Omar, N., S.A. Hassan, U.K. Yusoff, N.A. Psyquay-Abdullah, P.E. MegatWahab, and U.R. Sinniah. 2012. Phenolics, flavonoids, antioxidant activity and cyanogenic glycosides of organic and mineral-base fertilized cassava tubers. Molecules 17: 2378-2387.

Georgé, S., P. Brat, P. Alter, and M. Aminot. 2005. Rapid determination of poliphenols and vitamin $\mathrm{C}$ in plant-derived products. Journal of Agricultural and Food Chemistry 53: 1370-1373.

Godoy-Hernández, H., J.Z. Castellanos-Ramos, G. Alcántar-González, M. Sandoval-Villa, and J. Muñoz-Ramos. 2009. Efecto del injerto y nutrición de tomate sobre rendimiento, materia seca y extracción de nutrimentos. Terra Latinoamericana 2: $1-9$.

Hernández, A., H. Castillo, D. Ojeda, A. Arras, J. López, and E. Sánchez. 2010. Effect of compost on lettuce production. Chilean Journal of Agricultural Research 70: 583-589.

Hernández-Fuentes, A.D., R. Campos-Montiel, and J.M. Pinedo-Espinoza. 2010. Comportamiento postcosecha de pimiento morrón (Capsicum annum L.) var. California por efecto de la fertilización química y aplicación de lombrihumus.
Revista Iberoamericana de Tecnología Postcosecha 11: 82-91.

López-Espinosa, S.T., A. Moreno-Reséndez, P. Cano-Ríos, N. Rodríguez-Dimas, V. RobledoTorres, and C. Márquez-Quiroz. 2013. Organic fertilization: An alternative to produce jalapeño pepper under greenhouse conditions. Emirates Journal of Food and Agriculture 25: 666-672.

Medina-Juárez, L.A., D.M.A. Molina-Quijada, C.L. Del Toro-Sánchez, G.A. González-Aguilar, and N. Gámez-Meza. 2012. Antioxidant activity of peppers (Capsicum annuum L.) extracts and characterization of their phenolic constituents. Interciencia 37: 588-593.

Morales, F., and S. Jiménez-Pérez. 2001. Free radical scavenging capacity of maillard reaction products as related to colour and fluorescence. Journal Agricultural Food Chemistry 72: 119-125.

Nguyen, P.M., E.M. Kwee, and E.D. Niemeyer. 2010. Potassium rate alters the antioxidant capacity and phenolic concentration of basil (Ocimum basilicum L.) leaves. Food Chemistry 123: $1235-1241$.

Patthamakanokporn, O., P. Puwastien, A. Nitithamyong, and P.P. Sirichakwal. 2008. Changes of antioxidant activity and total phenolic compounds during storage of selected fruits. Journal of Food Composition and Analysis 21: 241-248.

Pavla, B., and R. Pokluda. 2008. Influence of alternative organic fertilizers on the antioxidant capacity in head cabbage and cucumber. Notulae Botanicae Horti Agrobotanici Cluj 36: 63-67.

Picchi, V., C. Migliori, R. Lo Scalzo, G. Campanelli, V. Ferrari, and L.F. Di Cesare. 2012. Phytochemical content in organic and conventionally grown Italian cauliflower. Food Chemistry 130: 501-509.

SE-Secretaria de Economía.2014.NMX-FF-025-SCFI-2013 Norma Official Mexicana. Productos alimenticios no industrializados para consumo humano - chile fresco (Capsicum spp). México, D.F. 30 pp.

Silva, J.D.C., T.T.B. Leal, A.S.F. Araujo, R.M. Araujo, R.L.F. Gomes, W.J. Melo, and R.P. Singh. 2010. Effect of different tannery sludge compost 
amendment rates on growth, biomass accumulation and yield responses of Capsicum plants. Waste Management 30: 1976-1980.

Smolen, S., and W. Sady. 2009. The effect of various nitrogen fertilization and foliar nutrition regimes on the concentrations of sugars, carotenoids and phenolic compounds in carrot (Daucus carota L.). Scientia Horticulturae 120: 315-324.

Steiner, A.A. 1984. The universal nutrient solution, p. 633-649. In: Proceedings of Sixth International Congress for Soilless Culture. International Society for Soilless Culture. Wageningen, The Netherlands.

Toor, R.K., P.G.P. Savagea, and A. Heeb. 2006. Influence of different types of fertilizers on the major antioxidant components of tomatoes. Journal of Food Composition and Analysis 19: 20-27.

Tundis, R., F. Menichini, M. Bonesi, F. Conforti, G. Statti, F. Menichini, and M.R. Loizzo. 2013. Antioxidant and hypoglycaemic activities and their relationship to phytochemicals in Capsicum annuum cultivars during fruit development. LWT - Food Science and Technology 53: 370-377.
Upadhyaya, S., J.J. Mahanta, and L.R. Saikia. 2011. Antioxidant activity, phenol and flavonoid content of a medicinal herb Andrographis paniculata (Burm.F.) nees grown using different organic manures. Journal of Pharmacy Research 4: 614-616.

Vázquez-García, E., M. Ramírez-Meraz, H. MataVázquez, R. Ariza-Flores, and I. Alia-Tejacal. 2010. Atributos de calidad y vida de anaquel de frutos de cultivares de chile serrano en México. Revista Fitotecnia Mexicana 33: 79-82.

Zaller, J.G. 2007. Vermicompost as a substitute for peat in potting media: Effects on germination, biomass allocation, yields and fruit quality of three tomato varieties. Scientia Horticulturae 112: 191-199.

Zhu, W., X. Lin, C. Jin, Y. Zhang, and P. Fang. 2009. Effects of nitrogen application rates on antioxidant contents and antioxidative activities in Chinese cabbage (Brassica chinensis L.). Journal of Zhejiang University (Agriculture and Life Sciences) 35: 299-306. 